\title{
Revistas médicas devem se "Qualificar"?
}

$\mathbf{P}$

or volta de 1996/1998, a Capes, órgão do MEC que avalia a pós-graduação brasileira, promoveu uma profunda modificação nesta. Na área médica, que é a que nos interessa no momento, tal reestruturação resultou em alterações viscerais.

Até então, era habitual que o médico, ao concluir sua residência médica ou curso de especialização, buscasse após um certo período em que atingisse estabilidade profissional e financeira, um mestrado na sua especialidade médica e, logo após mais um interregno para nova estabilidade, o doutorado.

Esse processo era feito em sua especialidade e, não raro, um doutor em medicina recebia o diploma, em média, por volta dos 45-50 anos de idade, um pouco tarde, convenhamos, para iniciar a produzir como pesquisador. Muitas teses não eram publicadas ou então eram em revistas de circulação apenas nacional. O doutor assim formado nunca mais se envolvia em pesquisa. O título tinha por finalidade demonstrar competência além da formação puramente "lato sensu".

A reestruturação promovida pela Capes alterou profundamente o perfil dos cursos "stricto sensu" em medicina (mestrados e doutorados). Estes passaram a ser focados na pesquisa científica e na produção científica, a do doutorado com maior exigência de qualidade. Houve a desvinculação entre a especialidade médica e o programa de mestrado e doutorado, cujo nome, modernamente, não mais necessariamente se vincula ao nome da especialidade. Hoje os programas possuem nomes mais abrangentes e identificados com as linhas de pesquisa médica que são conduzidas e não com a especialidade médica. Nomes modernos de programas de mestrado e doutorado são: Ciências Médicas, Ciências Biomédicas, Ciências Cirúrgicas, etc.

O candidato ao mestrado ou doutorado tem inserção nesses programas independentemente da sua especialidade médica. Se oftalmologista, por exemplo, ele pode entrar num programa de Ciências Médicas e fazer pesquisa envolvendo a oftalmologia, porém inserida numa linha de pesquisa em metabolismo, em imunologia ou em qualquer outra área onde o conhecimento seja desejável. Também é interessante que muitos desses programas não mais exijam a residência médica ou a especialização como pré-requisito, uma vez que mestrado e doutorado em medicina não se vinculam mais às especialidades médicas.

Tal novo perfil estimula a conquista do mestrado e doutorado mais cedo por parte dos médicos, convida à busca desses cursos por quem é vocacionado para a pesquisa e certamente torna tais programas mais difíceis para quem não os procura com finalidade de tornar-se professor ou pesquisador de fato, pois, como veremos a seguir, a dificuldade agora é maior para quem envereda por tal caminho.

Anteriormente, a tese era a estrela do mestrado ou do doutorado; agora, ela continua como requisito, mas a meta é a publicação do material resultante da tese em periódico chamado "de impacto". Com muita pertinência, decidiu a Capes que tese que não resulta em conhecimento novo e que não seja publicada em revista "de impacto", com grande circulação, em inglês e interessando a outros pesquisadores da comunidade científica mundial não faz sentido. Recursos investidos na formação de pessoal em nível de mestrado ou doutorado retornam com a formação do mestre ou do doutor e com a comunicação do produto da pesquisa, essencialmente em revista lida pela nata da pesquisa no campo do conhecimento. Argumenta a Capes que só assim o conhecimento é comunicado adequadamente e atinge o seu objetivo.

Surgiu, então, o "qualis", classificação adotada pela Capes que busca hierarquizar as revistas segundo um índice adotado universalmente no campo do conhecimento, que se denomina "fator de impacto". O "fator de impacto" é um índice matemático que busca nos dizer qual a importância da revista para a comunidade de cientistas da área, em função dos artigos ali publicados serem muito lidos por outros pesquisadores e também citados por esses nos artigos que escrevem posteriormente. O "fator de impacto" é uma espécie de nota para a revista, nos diz o quanto ela é lida e com que freqüência os artigos nela publicados são citados por pesquisadores. Repare o leitor que grifei, de propósito, o termo pesquisadores.

Atualmente o "qualis" da Capes para a medicina divide as revistas médicas em 8 estratos, segundo o "fator de impacto" da revista. O "fator de impacto" é calculado anualmente pelo ISI, um instituto internacional especializado nesta tarefa. A revista é qualis $\mathbf{A 1}$ se tem fator de impacto (FI) acima de 3,8; $\mathbf{A 2}$ se FI entre 2,3 e 3,79; B1 se FI entre 1,0 e 2,29; B2 se FI abaixo de 1,0, porém diferente de zero; B3 se está no Medline ou no Pubmed, mas com FI de zero; 
B4 se está no Scielo; $\mathbf{B 5}$ se pertence ao Lilacs; se não pertence a nenhuma das bases de dados citadas acima, a revista é considerada $\mathbf{C}$.

Como qualquer um poderá verificar, trata-se de uma classificação bastante rigorosa, que tem a peculiaridade de se basear em critérios científicos e que atende aos pesquisadores no seu labor diário. Quero dizer com isso que artigos publicados em revistas de alto "fator de impacto" não raro são pouco acessíveis ao médico que não milita no campo da pesquisa, que não trabalha em bancada, por exemplo, e que não tem boas noções de epidemiologia.

Como já tenho feito em diversas outras ocasiões, chamo a atenção para o fato de que a classificação adotada pela Capes é uma classificação dirigida a pesquisadores, tem como meta hierarquizar revistas em função de conhecimento novo produzido. Tais periódicos publicam artigos originais, em esmagadora maioria, muitos deles veiculando conhecimento novo, que muitas vezes inclusive será refutado, não vindo a se consolidar para uso na prática médica diária.

Pessoalmente continuo a achar muito importante a função das revistas médicas que divulgam bom conhecimento já consolidado através de publicação de casos clínicos, de sessões, de revisões, cujo papel, na minha opinião, parece bem mais importante para a atualização contínua do médico. Essas publicações estão rareando.

Isso não significa que eu ache que o médico prático não deva ler periódicos de alto impacto, mas é ilusão achar que o médico prático vai se atualizar lendo somente, ou mesmo preferencialmente, periódicos de alto impacto. Os artigos publicados nas revistas de impacto são complexos, usam métodos sofisticados de pesquisa médica, não só quanto aos métodos adotados, quanto também aos modelos epidemiológicos.

Assistimos hoje a uma febre na tentativa de "qualificação" de revistas médicas brasileiras, sem que se tenha noção do que significa essa "qualificação". "Qualificar" significa passar a aceitar para publicação na revista quase que somente material original, proveniente de pesquisa, cada vez mais sofisticada. Saem as revisões, os casos clínicos, as sessões e o leitor vai passar a entender cada vez menos do material publicado a cada número. Obviamente seu interesse na revista, sendo médico prático, irá diminuir. Se for um cientista da área, talvez seu interesse cresça. Muitas de nossas revistas, ao conquistarem a "qualificação" (que tem como parâmetro o critério do pesquisador, insisto, não o do médico prático) e ao "subirem" na hierarquia do "qualis" da Capes, tornam-se bem menos úteis ou interessantes para quem milita na assistência médica e não atua nem como professor, nem como pesquisador.

Poder-se-ia argumentar que o médico precisa aumentar seus conhecimentos de pesquisa, epidemiologia e estatística e isso, certamente, é desejável. Porém, em meio a tanta correria profissional, realidade dos dias em que vivemos, como fazer isso e, principalmente, como manter isso?

As faculdades de medicina já estão introduzindo nos seus currículos disciplinas de iniciação científica que visam dar a todos os médicos, até se formarem, uma formação científica mais sólida. Isso, contudo, leva tempo. Mesmo com tal formação, o médico prático, sem cultivar tais conhecimentos regularmente, dificilmente se sentirá confortável lendo artigos de ponta com métodos e estatísticas complexos ao seu entendimento.

São desafios, questionamentos, reflexões e sugestões que deixo para a discussão dos amigos leitores da RBO, desculpando-me por haver me estendido além do desejável e agradecendo a honra de ter sido convidado pelo professor Riuitiro para conversar despretensiosamente com os colegas sobre um tema que me interessa bastante, pois diz respeito à formação e aperfeiçoamento médicos, campo de trabalho a que muito me afeiçoo.

\section{Gilberto Perez Cardoso \\ Professor titular do departamento de Clínica Médica da Universidade Federal Fluminense - Rio de Janeiro (RJ), Brasil}

